\title{
Corporations, Universalism and the Domestication of Race in International Law
}

\author{
Sundhya Pahuja
}

\begin{abstract}
In this chapter, I will contrast two normative approaches to the question of justice between peoples which emerged during the period of decolonization in the Twentieth Century, and which circulate in international law and institutions. These approaches have struggled through the period of the 'Cold War' to the present day. The first, underpinned by an historically decontextualized, moral universalism, sees 'poverty' as a threat to world peace, prosperity and security and its 'alleviation' as a gesture of enlightened self-interest. The second is inflected by an historical and political-economic understanding of global inequality as resulting from an active impoverishment of the Third World by the First World during the period of imperialism, and potentially remediable through the acquisition of statehood and the development and deployment of international law. The concept of race figures in each of these approaches in different ways, but has merged over time to divorce racialized disparities from analyses of global economic inequality. In order to illustrate this struggle, and the changed analytical valency of race, I will trace the attempt made in the 1970's, by the 'Group of 77 ' states, to assert international legal control over trans or multi-national corporations, and the contemporaneous response by the West, which prefigured the transformation of the initiative after the end of the Cold War. This example is a site in which the rival accounts of 'global justice' did battle. Re-reading this struggle with race in mind, both suggests what might be at stake in their competing political and jurisprudential visions and reveals the racialized underpinnings of the way that authority and responsibility are distributed in international law and institutions today.
\end{abstract}

International law does not recognize any distinctions...based on religious, geographical or cultural differences.

Oppenheim's international law, (1997) p41

\section{Introduction}

In 1960, Frantz Fanon, a Martiniquan, French trained psychiatrist, wrote not long before his death ${ }^{2}$ that when '[l]ooking at the immediacies of the colonial context, it is clear that what divides this world is first and foremost what species, what race one belongs to. In the colonies the economic infrastructure is also a superstructure. The cause is effect: You are rich because you are white, you are white because you are rich. ${ }^{3}$ Some forty years later, in a seminal article about 'global justice', philosopher Thomas Pogge wrote, '[w]e are quite tolerant of the persistence of massive and severe

\footnotetext{
${ }^{1}$ Robert Jennings and Arthur Watts (eds.), Oppenheim's International Law: Volume 1 (London: Oxford University Press, 1997), 4.

2 Fanon died on 6 December 1961 in Bethesda, Maryland where he was undergoing treatment for Leukemia. He was writing in the context of the ongoing colonial status of Algeria, two years before Algeria became independent. (Algeria became independent in July 1962).

${ }^{3}$ Frantz Fanon, The Wretched of the Earth, trans. Richard Philcox (New York: Grove Press, 1963), 5.
} 
poverty abroad even though it would not cost us much to reduce such poverty dramatically. How well does this tolerance really fit with our commitment to moral universalism ${ }^{\prime 4}$

The juxtaposition of these two texts is intriguing. It invites us to consider how we can understand the difference - and relationship - between them. Although in different poetic registers, they each centre on the question of material distribution beyond the bounds of the nation-state. Each gestures towards an account of a relation with those outside one's community, Fanon in a critical register, Pogge in a normative one. For Fanon, the question of economic inequality can be separated neither from history in general, and the history of colonialism in particular, nor from the question of race. In other words, race, history and economics are intertwined. This is not because race is 'real' as a biological or genetic fact - quite the contrary. Instead, it is because race was - and remains - an operative (historical) category in the constitution of the 'human'. For Fanon, race is 'sociogenic' - a socially co-produced fact ${ }^{5}$ through which a skin tone becomes a status. This socio-genesis is linked centrally to economic structures. In asserting that 'you are rich because you are white', as well as its inverse, 'you are white because you are rich', Fanon is both pointing to the centrality of capitalism in the socio-genesis of 'race', and more radically, asserting that capitalist accumulation is grounded in racial differentiation itself. This grounding endures even after biological racism is discredited scientifically, at which point cultural racism, or Eurocentrism, performs its work. As Shatz puts it, for Fanon, 'the defence of 'Western values' had superseded biological racism in the arsenal of imperialism. ${ }^{6}$

For Pogge, on the other hand, speaking from the dawn of the twenty-first century - the question of 'global justice' is a new one; '[e]arlier generations of European civilization were not committed to moral universalism'. ${ }^{7}$ The causes too, of the unequal distribution of wealth are proximate, and race belongs in a separate category to economics. 'Skin color, or ancestry' is relevant to his argument insofar as it is 'disqualified' it as a basis for the unequal assignment of 'fundamental moral benefits'. In other words, the ethical position of this approach is a colour-blind universalism. It's no coincidence that the register is normative. This is an orientation which directs the reader toward an horizon of futurity, and away from historical causes. ${ }^{8}$

\footnotetext{
4 Thomas Pogge, 'Moral universalism and global economic justice', Politics, Philosophy and Economics, 1/1 (2002), 29-58, 30.

${ }^{5}$ See Lewis Gordon et al., What Fanon Said: A Philosophical Introduction to His Life and Thought (New York: Fordham University Press, 2015), especially at 2, 138. On 'co-production', see Sheila Jasanoff, States of Knowledge: The CoProduction of Science and the Social Order (London: Routledge, 2004), introductory essay.

${ }^{6}$ Adam Shatz, 'Where Life Is Seized', London Review of Books, 39/2 (2017), 19-27.

7 Pogge (2002), above $n 4$.

8 Thomas Pogge, 'Recognized and Violated by International Law: The Human Rights of the Global Poor', Leiden Journal of International Law, 18 (2005), 717-745, 723.
} 
In one sense, Fanon and Pogge can be read heuristically as avatars for two distinct approaches to the question of material deprivation, as both a world, and worldly concern. Each approach has a different view about how to understand the problem, what its causes might be, where the authority to decide how to tackle it might be located, and where the responsibility to address it may lie. These approaches take international institutional form in the encounters between the three 'worlds'; First, Second and Third, in the emergent years of what we might call bureaucratic multilateralism, and track the development and expansion of international institutions. But in another sense, the texts bookend a particular period during which we see race gradually disappear as an axis of analysis from international legal and institutional accounts of inequality. This erasure happens precisely through the 'supercession' of biological race by culture, and the production of a developmental scale which contains cultures within the territorial bounds of nation-states, and places them in a hierarchy, organised according to their 'stage of development'. Once a developmentalist ordering is taken up, what is forgotten is that the hierarchy reproduced is the same as the one generated by the imperial 'science' grounded in (biological) race and racism. When domesticated as a concern of the national sphere, race is no longer understood to be a global practice of ordering; neither global nor economic structures are understood to play a generative role in its socio-genesis. ${ }^{9}$

In this chapter, I will draw out what is at stake in the differences between the two approaches - as well as in the convergences between them - by focusing on one episode in the ongoing series of encounters between them in the first fifty years of bureaucratic multilateralism. This version of the international was inaugurated with the establishment of the contemporary institutions of international law after the second world war. Our time frame here ends with the end of the Cold War. The writings of Fanon and Pogge bookend this period in an uncanny, if not tragic, way. ${ }^{10}$ The episode centres on the attempt starting in the late 1960's, by the Third World to assert international institutional control over transnational corporations, and the response to that assertion by a key group of powerful Western states, particularly the United States. To sharpen the account for our purposes here, I close in on an 'exchange' between Salvador Allende, then President of Chile, and Henry Kissinger, then US Secretary of State, conducted indirectly through institutional speeches. Although the relationship between the institutional debates about the multinational corporation, and the question of 'global justice', race and international law may at first seem oblique, the battle turns out

\footnotetext{
${ }^{9}$ Siba Grovogui, 'Deferring difference: a postcolonial critique of the 'race problem' in moral thought' in Sanjay Seth (ed.), Postcolonial Theory and International Relations: A Critical Introduction (London: Routledge, 2012), 106-123; John Agnew, 'The Territorial Trap: The Geographical Assumptions of International Relations Theory', Review of International Political Economy, 1/1 (1994), 53-80.

10 For an account of the 'narrative arc of tragedy' see Simon Critchley, 'Tragedy's Philosophy and Philosophy's Tragedy' (Humanities Center Annual Lecture, Brigham Young University, 2014).
} 
to be revelatory of the way that embedded hierarchies of race (still) order the global economy, and helps us to understand the relationship between such hierarchies, and the patterns of the distribution of authority, responsibility - and wealth - in the world today.

\section{Duelling Speeches - Allende v Kissinger}

\section{Allende}

In 1972, the Third Session of the newly formed United Nations Conference on Trade and Development, was held in Santiago, Chile. ${ }^{11}$ As president of the country hosting the event, Allende gave the opening speech. ${ }^{12}$ In a clarion call to action, Allende outlined the mission of the Third Session as continuing the work begun with decolonisation, and institutional initiatives to reform international economic structures of replacing the 'outdated and essentially unjust economic and trade order'. ${ }^{13}$ Even after the demise of formal colonialism in many parts of the world, it was clear to Allende, that many countries 'exist[ed] under unbearable conditions...their economy [being] dominated by foreign powers; outsiders hold[ing] all or part of their territory; still endur[ing] the yoke of colonialism...deep social disparities [were] oppress[ing] the masses and benefit[ing] only the privileged few' ${ }^{14}$ Like Fanon, Allende understood that poverty is produced by economic arrangements, and is not a natural state of being. Similarly, for Allende like Fanon, the generation of wealth and the production of poverty exist in 'a clear-cut dialectical relationship': 'imperialism exists because under-development exists; under-development exists because imperialism exists. ${ }^{15}$

For Allende, transnational corporations were central to the problem. In his account, their further expansion would be fatal to the new worlds being made through Third World solidarity, inaugurated in institutional terms at the Bandung Conference in $1955^{16}$ and made manifest in calls for a New International Economic $\operatorname{Order}^{17}$ and the possibility of remaining 'non-aligned' in the struggle between

\footnotetext{
11 Diego Cordovez, 'The Making of UNCTAD: Institutional background and legislative history', Journal of World Trade Law, 1/3 (1967), 243-328, 272.

12 Salvador Allende (Republic of Chile), 'Address delivered at the Inaugural Ceremony', Proceedings of the United Nations Conference on Trade and Development (13 April 1972, Santiago, Chile); Salvador Allende (Republic of Chile), 'Address delivered at 2096 $6^{\text {th }}$ Plenary Meeting', Official Records of the United Nations General Assembly (4 December 1972, New York).

${ }^{13}$ Allende UNCTAD (1972), Ibid, [9].

${ }^{14}$ Allende UNCTAD (1972), Ibid, [12].

15 Allende UNGA (1972), above n 12, [65].

${ }^{16}$ Luis Eslava et al. (eds.), Bandung, Global History, and International Law: Critical Pasts and Pending Futures (Cambridge: Cambridge University Press, 2017).

17 Jennifer Bair, 'Taking Aim at the New International Economic Order' in Philip Mirowski and Dieter Plehwe (eds.), The Road from Mont Pèlerin: The Making of the Neoliberal Thought Collective (Cambridge: Harvard University Press, 2009), 347-85; Mohammed Bedjaoui, Towards a New International Economic Order (New York: Holmes and Meier Publishers, 1979).
} 
the nominally anti-imperial, American and Soviet empires. ${ }^{18}$ In Allende's view, the unchecked power of ever-expanding corporations would also scuttle the possibility of co-operation, and diplomatic exchange, between the 'industrialised' countries and what had already become known by then as the 'developing countries'19. With this speech, the question of the large multinational corporation was thrust onto the stage of international institutionalism.

Allende's speech must have been electrifying given the context. A contemporaneous report from 1972 in The Observer reads:

Western delegates, expecting a platitudinous inauguration, writhed in their seats as the Chilean leader, conscious that he was speaking for virtually the whole of the Third World, tore into the trade and aid practices of rich countries. [...] Few orators could successfully have followed that speech [...] As Allende left the rostrum [covered symbolically in copper]. The atmosphere was electric. One Western European Cabinet Minister looked almost apoplectic. A Scandinavian delegate chuckled quietly that one could have expected nothing less from a country which was being squeezed in a vice by the US. ${ }^{20}$

The speech is often remembered for its strong critique of interference by corporations in the political and economic sovereignty of Chile. It turns out Allende was right to be concerned. The companies he mentioned in 1972 as being intent on destabilizing the democratically elected government because it pursued a socialist agenda (including nationalizing the copper and telecommunications industries), had, by 1973 , with the complicity of the CIA, fomented the coup which toppled the elected government, led to Allende's death, and installed general Augusto Pinochet as president of Chile. ${ }^{21}$

Although that is how it is primarily remembered, Allende himself was concerned not just with the question of the present interference in Chile's sovereignty. Instead, he drew a longer historical arc, referring to colonialism as well as to the Monroe doctrine of $1823,{ }^{22}$ and the Roosevelt Corollary of

\footnotetext{
18 Natasa Miskovic et al. (eds.), The Non-Aligned Movement and the Cold War: Delhi-Bandung-Belgrade (New York: Routledge, 2014); Hani Sayed, 'The Humanization of the Third World' in Luis Eslava et al. (eds.), Bandung, Global History, and International Law: Critical Pasts and Pending Futures (Cambridge: Cambridge University Press, 2017), 431-449; William Louis and Ronald Robinson, 'The Imperialism of Decolonization' in James Le Sueur (ed.), The Decolonization Reader (London: Routledge, 2003), 49-79.

${ }^{19}$ Allende UNGA (1972), above $n$ 12, [60].

${ }^{20}$ Hugh O’Shaughnessy, 'Poor Nations Warn: Give Us a Better Deal or Else', The Observer, 16 April 1972.

${ }^{21}$ Anthony Sampson, The Sovereign State: The Secret History of ITT (London: Hodder and Stoughton, 1973); United States Senate, 'First Session, Volume 7: Covert Action', Hearings Before the Select Committee to Study Governmental Operations with Respect to Intelligence Activities (Ninety Fourth Congress, 1975). Available at https://www.intelligence.senate.gov/resources/intelligence-related-commissions [website last visited 5 June 2018]. 22 Mark Gilderhus, 'The Monroe Doctrine: Meanings and Implications', Presidential Studies Quarterley, 36/1 (2006) 5-16; Juan Pablo Scarfi, 'In the Name of the Americas: The Pan-American Redefinition of the Monroe Doctrine and the Emerging Language of American International Law in The Western Hemisphere, 1898-1922', Diplomatic History, 40/2 (2016) 189-218.
} 
1904, which ostensibly protected Latin America from recolonization by European states, but asserted a US right to intervene in the continent to prevent "flagrant and chronic wrongdoing by a Latin American Nation". ${ }^{23}$ The gesture is part of a pattern of that time (and beyond), in which Western states, and the institutions in which they were dominant, repeatedly inaugurated the world anew, describing the decolonised nations as 'new', or 'emerging' states, 'entering' the world for the first time. ${ }^{24}$ For the Third World, on the other hand, the present was historical, linked to what had gone before through the legacies of empire, and in emergent neo-imperialisms. ${ }^{25}$ For them, diplomacy after empire was in large part an historiographical enterprise, involving a need to assert a continuity between pre- and post- colonial civilisations in the non-West, and to reclaim a 'rightful place' in history for those civilisations. ${ }^{26}$

As well as making an historiographical assertion in general, Allende was also concerned in particular, with how to understand the modern corporation in its historical context. In his account, that entity too was historically grounded, the transnational corporation existing on a continuum with colonial companies. Unlike the 'private' entities they were said to be in the American jurisprudence flexing its muscle through Marshall plan interventions at the time, ${ }^{27}$ transnational corporations were better understood as political entities, for they had long been experienced in the Third World as both carrying out political functions, and exercising public authority. ${ }^{28}$ For Allende, this experience produced two axes of concern. The first was how to manage the conduct and activities of transnational corporations; the second was the question of how corporations came to acquire assets, and how they were protected. We can think of these two axes as the 'conduct' and 'property' axes respectively.

\footnotetext{
${ }^{23}$ There is a version of this doctrine on the website of the Office of the Historian of the United States: Department of State, United States of America, 'New Policies for Latin American, Asia', Office of the Historian (n.d.). Available at:

https://history.state.gov/departmenthistory/short-history/newpolicies [website last visited 13 June 2018]. For analysis, see Gilderhus (2006), Ibid.

${ }^{24}$ Sundhya Pahuja, 'Letters from Bandung' in Luis Eslava et al. (eds.), Bandung, Global History, and International Law: Critical Pasts and Pending Futures (Cambridge: Cambridge University Press, 2017), 552-573.

25 On the 'durability' of imperial modes of thought and a challenge to the idea of the 'post' colonial, see generally, Ann Laura Stoler, Duress: Imperial Durabilities in our Times (Durham: Duke University Press, 2016).

${ }^{26}$ For one example of this gesture at the level of the state, see Jawaharlal Nehru, 'Meeting Ground of East and West' (Speech given in the Constituent Assembly (Legislative) of India, 8 March 1949, New Delhi, India). Reproduced in Ministry of Information and Broadcasting, 'Jawaharlal Nehru's Speeches, Volume I: September 1946 - May 1949' (Coimbatore: Government of India Press, 1967). See also Upendra Baxi, 'Some Remarks on Eurocentrism and the Law of Nations' in R.P. Anand (ed.), Asian States and the Development of Universal International Law (New Delhi: Vikas Publications, 1972), 3-9.

${ }^{27}$ Terence Gourvish and Nick Tiratsoo (eds.), Missionaries and Managers: American Influences on European Management Education, 1945-60 (New York: Manchester University Press, 1998), 3; Paddy Ireland, 'Defending the Rentier: Corporate Theory and the Reprivatization of the Public Company' in John Parkinson et al. (eds.), The Political Economy of the Company (Oxford: Hart, 2001), 141-174.

${ }^{28}$ Bedjaoui (1979), above $n$ 17, 36-37: "The present situation, with the multinational companies, is even more alienating for the under-developed countries than it was in the colonization period with the chartered companies".
} 
In terms of the first axis, the conduct question, Allende was concerned to ensure that all states should have the ability to assess for themselves, whether transnational corporations doing business in their territories were making a contribution to the economic development of the country as a whole. Like many in the Second and Third Worlds, Allende understood that the devil of 'foreign investment' is in the detail, ${ }^{29}$ including the density of linkages between the company's operations and the local economy and society as a whole, the extent of the repatriation of profits, the use of 'restrictive business practices', such as invoking intellectual property regimes to prevent technology transfer to the state 'hosting' the investment, the issue of environmental degradation, and the conditions of work promoted by the corporation.

In terms of the second axis, how companies had acquired investments and how they were protected, Allende was mindful of the way that during the 19th century the major European powers had 'propagate[d] Western standards of individual ownership around the world and secure[d] these standards in the face of considerable social, cultural, [legal] and political diversity ${ }^{30}$ in order to facilitate the security of foreign investment. In the process, they displaced or radically transformed collective forms of ownership and systems of use rights (or confined them to 'native' sectors of dual economies), and created regimes of private property as part of a politically guaranteed 'order' for European states through a variety of means 'ranging from [direct] colonialism to extraterritorial laws to informal commercial empire'. ${ }^{31}$ Although the language of law was used by some to justify these actions, these practices were highly contested, and not accepted at the time as anything like the 'international legal order', they are now often retrospectively described as having reflected.

From the perspective of the West, this 'order' was asserted as something like an 'international law governing expropriation of foreign investments', ${ }^{32}$ imposing strict 'minimum standards' on all states, and requiring full compensation for expropriation. In keeping with the assertion of legality, these particular values were cast as universal, and enforcement of this 'standard' was closely intertwined with empire and intervention. As Detlav Vagts put it, 'at the high tide of this version of international law, breaches by host countries might be avenged by any number of plagues ranging from gunboats to arbitration. ${ }^{33}$ But even from the inside of this 'system', such as it was, there was uncertainty over

\footnotetext{
29 David Fieldhouse, The West and the Third World: Trade, Colonialism, Dependence and Development (Oxford, WileyBlackwell Publishing, 1999), 254-286.

${ }^{30}$ Charles Lipson, Standing Guard: Protecting Foreign Capital in the Nineteenth and Twentieth Centuries (Berkeley: University of California Press, 1985), 20.

31 Lipson (1985), Ibid, 21.

32 Lipson (1985), Ibid, 24.

${ }^{33}$ Detlev Vagts, 'The Global Corporation and International Law', Journal of International Law and Economics, 6 (1972), 24762, 254.
} 
the status of 'foreign property' as a question of international law. Imperial states had, in any case, jurisdiction over their own colonies, as well as their colonies' foreign affairs. ${ }^{34}$ And the force of the Russian revolution and Mexican nationalisations of the early twentieth century, meant that there was no legal or institutional resolution at the League of Nations over the question of whether foreign owned private property should be granted international protection. ${ }^{35}$

But as the post war period went on and agitation for decolonisation increased, tremors began to shake the 'system'. The most notable example is perhaps the nationalisation of the Anglo-Iranian Oil company by the democratically elected prime-minister Mohamed Mossadeq in Iran in $1951 .{ }^{36}$ As decolonisation proceeded, the quakes became more frequent, as both the substance of the asserted 'rules' protecting foreign owned private property, and the preferred modes of 'enforcement', were subject to radical challenge. From the perspective of the West, this was perceived as a crisis of 'legitimacy'. ${ }^{37}$ But from the perspective of the Second and Third Worlds, it represented the beginning of another struggle, this time to remake the international economic order after empire, and to offer a wholesale challenge to the political-economic legacies of colonialism.

The response of the West in the face of this challenge was to experiment with a new mode of postcolonial enforcement to protect foreign owned private property: intervention by the American Central Intelligence Agency, underpinning corporate/state alliances. ${ }^{38}$ This was not the sole province of the United States. Recently declassified documents have revealed that Cold War paranoia was actively mobilized by weakened imperial powers, such as Britain, to persuade the United States to help protect the property of their investors. ${ }^{39}$ Again, the Iranian example is a case in point as Mossadeq's nationalisations prompted a coup, assisted by the CIA, which reinstalled the Shah. ${ }^{40}$ But as this new mode of protecting foreign property began to surface, in Chile certainly, and people suspected even then in Iran - the 'legitimacy' of the imperial regime was eroded further still, and

\footnotetext{
34 John Grant and Craig Barker, Encyclopaedic Dictionary of International Law (Oxford: Oxford University Press, 2009): 'Colonial Clause' citing Lord McNair, The Law of Treaties (Oxford: Oxford University Press, 1986), 118-119. (Similar clauses are now commonly styled territorial application clauses, see Anthony Aust, Modern Treaty Law and Practice (Cambridge: Cambridge University Press) Chapter 11.

${ }^{35}$ Arghyrios Fatouros, 'An International Code to Protect Private Investment: Proposals and Perspectives', University of Toronto Law Journal, 14 (1961) 77-93, 79.

${ }^{36}$ Sundhya Pahuja and Cait Storr, 'Rethinking Iran and International Law: The Anglo-Iranian Oil Company Case Revisited' in James Crawford et al. (eds.), The International Legal Order: Current Needs and Possible Responses, Essays in Honour of Djamchid Momtaz (Leiden: Brill, 2017), 53.

${ }^{37}$ See generally, Lipson (1985), above $n 30$.

${ }^{38}$ For a list of instances, see William Blum, Killing Hope: U.S. Military and C.I.A. Interventions Since World War II (Maine: Common Courage Press, 2008).

${ }^{39}$ This was done through the Information Research Division, a secret division of the British Foreign Office. Andrew Rubin, Archives of Authority: Empire, Culture and the Cold War (New Jersery, Princeton University Press, 2012), $20,34$.

40 Pahuja and Storr (2017), above n 36, 53, 74.
} 
resistance to it, even from inside the United States, increased. ${ }^{41}$ This erosion of legitimacy, combined with the existence of the different imaginary offered by communism $(s),{ }^{42}$ the political ballast of interworld rivalry, and the visible manifestations of Third World solidarity, created the space for the assertion of the Third World as a juridical, and not simply political, project. The particular terms of the juridical assertion now being forcefully made, related to the distribution of legal authority. Specifically, the Third World asserted that the conduct of foreign corporations should be regulated by international law, and that authority to admit, restrict or expropriate foreign investment, should rest with the nation-state. An international approach was needed to address the conduct question because of the collective action problem engendered by the hypermobility of the elements of production. National authority was needed over the foreign ownership of property question as a response to imperialism.

In asserting that international law should govern the (corporate) conduct question, and that national law should govern the (foreign) property question, Allende's conception of the corporation becomes important. He shared with those in both colonial and semi-colonial places, an enduring experience of the corporation as a 'real' entity. ${ }^{43}$ It was neither a child of the state,${ }^{44}$ nor a mere 'nexus of contracts ${ }^{45}$ Instead, for Allende, the corporation was an organic entity which exists regardless of the state. For him, it was an associational form adjacent to the state, asserting a distinct form of authority, and acting according to a rival form of law. ${ }^{46}$ In Allende's assessment, the secret of the corporation's power was its rootlessness in both effective and affective terms; ' $[\mathrm{m}]$ erchants have no country of their own. Wherever they may be they have no ties with the soil. All they are interested in is the source of their profits. ${ }^{47}$

But if he understood that mobility gave corporations power, then he also understood that the justifications for, or 'rightfulness' of that power, lay in the relationship that corporations claimed to bear to 'development'. In his speech at UNCTAD III, Allende reminded the assembled crowd, that

\footnotetext{
41 United States Senate (1975), above n 21.

42 In both its Chinese and Soviet versions. See Jeremy Friedman, Shadow Cold War: The Sino-Soviet Competition for the Third World (Chapel Hill: University of North Carolina Press, 2015).

${ }^{43}$ See generally, Otto von Gierke, Political Theories of the Middle Age, trans. Maitland (Cambridge: Cambridge University Press, 1902; reprint 1951), xxvi.

44 John Dewey, 'The Historic Background of Corporate Legal Personality', Yale Law Journal, 35/6 (1926) 655-673. Some will recognise Von Savigny's 'fiction theory' here. For one example of the reception of that theory, see, Martin Petrin, 'Reconceptualizing the Theory of the Firm - From Nature to Function', Penn State Law Review, 118/1 (2013) 1-53, 4-6. ${ }^{45}$ The seminal article here is Michael Jensen and William Meckling, 'Theory of the firm: Managerial behaviour, agency costs and ownership structure', Journal of Financial Economics, 3/4 (1976) 305-360.

${ }^{46}$ von Gierke (1902), above n 43. See also, David Ciepley, 'Beyond Public and Private: Toward a Political Theory of the Corporation', American Political Science Review, 107/1 (2013) 139-158.

${ }^{47}$ Allende UNGA (1972), above $n$ 12, [59].
} 
foreign corporations invariably represented their actions as being in the interests of those whose resources they exploit, and that transnational corporations 'arrogate to themselves the role of agents promoting the progress of the poorer countries'. ${ }^{48}$ Through this arrogation, such corporations 'have become a supranational force that is threatening to get completely out of control'49. In other words, this rhetorical merger between self-interest and altruism ${ }^{50}$ - a contemporary repurposing of Fredrick Lugard's 'dual mandate' for the present day - was the secret of the corporation's asserted authority to do business in the Third World. In this, corporations were key actors in the self-proclaimed duty of the West to develop the rest as an exogenous exercise of authority, and the alleviation of poverty as a gesture of enlightened self-interest. Allende makes clear that this idea of development provided (juridical) authority for the activities of transnational corporations.

In Allende's account, the better concept of development was an endogenous one, 'self-determined and independent', ${ }^{51}$ rather than the exogenous conception of the industrialised states, which he knew all too well, was grounded in a hierarchy that would condemn the 'under-developed countries' to a 'second-class, eternally subordinate status'. ${ }^{52}$ This conception of development, ideally determined by each state according to its needs, and shaped through their own political authority, was nonetheless a response to the shared condition of 'under-development', ${ }^{53}$ an economic state arising from the depradations of imperialism. What was happening in Chile was 'opening up a new stage in the battle between imperialism and the weaker countries of the Third World. ${ }^{54}$ This shared history was giving rise to collective action between Asia, Africa and Latin America. Allende describes with gratitude, the expression of 'complete solidarity' with Chile offered by the 'spokesman of the African group of States in the Trade and Development Board' over the issue which 'represented a potential threat to the entire developing world. ${ }^{55}$

But if Allende, like Fanon, understands the present as history, is aware of the centrality of historiography to international legal and diplomatic encounters between the 'Worlds', and has a keen awareness that the generation of wealth and the production of poverty are two sides of the same

\footnotetext{
48 Allende UNCTAD (1972), above n12, [58].

${ }^{49}$ Allende UNCTAD (1972), ibid, [58].

50 Gilbert Rist, The History of Development: From Western Origins to Global Faith (London: Zed Books, 2014).

${ }^{51}$ Allende UNGA (1972), above $n$ 12, [6].

52 Allende UNGA (1972), Ibid; Joseph Hodge, 'Writing the History of Development (Part 1: The First Wave)', Humanity, 6/3

(2015) 429-463; Joseph Hodge, 'Writing the History of Development (Part 2: Longer, Deeper, Wider)', Humanity, 7/1 (2016)

125-174; Sundhya Pahuja, Decolonising International Law: Development, Economic Growth and the Politics of Universality

(Cambridge: Cambridge University Press, 2011).

53 Allende UNGA (1972), above n 12, [65].

${ }^{54}$ Allende UNGA (1972), Ibid, [64].

${ }^{55}$ Allende UNGA (1972), Ibid.
} 
process, he is less attentive to the persistence of racialized thinking in these same practices of world ordering. The hierarchical arrangement of 'sovereign' states in a developmental scale, after all, looks very like the imperial, race based, heirarchy. And Allende falls back into those racialized heirarchies of imperialism, mapping developmental grids onto (global) lines drawn by colour, drawing attention to the 'thousands of people living in shanty towns' in the 'much-admired cities of Latin America', 'whose nutrition and health standards are no higher than in Africa' ${ }^{56}$ And although 'dramatic deficiencies in housing, work, food and health' are visible in Latin America, 'the situation is even worse in Asia and Africa, with their lower per capita income and weaker development process. ${ }^{57}$

Once a developmentalist ordering is taken up, it becomes 'common sense in the creation of a normative regime that [is at its core, a] technolog[y] of power, legitimation and affect', giving rise to a tendency to conceal the mechanisms of subordination [...] that operate through time and space through scientific method... ${ }^{58}$ What is forgotten is that the hierarchy reproduced, is the same one generated by the imperial 'science' grounded in (biological) race and racism. And so we see that already by the time of Allende's attempt to wrest legal authority from the first world over regulating the local acquisition of property of transnational corporations, and to assert over corporate conduct, a version of international law 'not subordinated to capitalist interests', ${ }^{59}$ the global dimensions of 'race' had already begun to become less visible in the international institutional setting. Race was being superseded by culture, and conceptually confined to the national sphere through the discourse of development.

\section{Kissinger}

At around the same time as the first session of the newly established UN Commission on Transnational Corporations took place in March of 1975, on September 1 of the same year the General Assembly of the UN held a Special Session on Development and Economic Co-operation. The session was planned as part of the ongoing institutional efforts to establish the principles of a New International Economic Order. ${ }^{60}$ And although the question of a binding treaty to hold transnational corporations to international legal standards of behaviour had already fallen off the new UNCTC's programme of work

\footnotetext{
56 Allende UNGA (1972), Ibid, [73].

57 Allende UNGA (1972), Ibid, [75].

58 Grovogui (2012), above n 9, 121.

59 Allende UNGA (1972), above $n$ 12, [49].

60 This was in the wake of the Declaration establishing a New International Economic Order at the UN General Assembly in 1974: United Nations General Assembly, 'Declaration on the Establishment of a New International Economic Order', GA Res 3201 (S-VI), 1 May 1974, UN Doc A/RES/S-6/3201.
} 
(and despite Allende's death during the Chilean coup on September 11, 1973), the question of corporations was very much alive at the General Assembly session.

The purpose of the gathering was to consider 'new concepts and options with a view to promoting effectively the solution of world economic problems, especially those of developing countries' ${ }^{61} \mathrm{At}$ the very forefront of the session was the United States. ${ }^{62}$ Then US Secretary of State, Henry Kissinger, was due to deliver a speech at the beginning of the proceedings. As it turned out, he was drawn away by the conclusion of the Sinai Pact between Egypt and Israel, ${ }^{63}$ but his speech was read in his absence by Daniel Moynihan, US Representative to the UN. The speech, called 'Global Consensus and Economic Development' announced the moment as 'an opportunity to improve the condition of mankind.' The United States, Kissinger announced, was committed to 'a programme of practical steps' to address the concerns of the developing world. ${ }^{64}$ The impelling circumstances were twofold. First, the inaugural availability of 'technical capacity' to 'provide a tolerable standard of life for the world's 4 billion people', and secondly, a 'point of moral choice' precipitated by the availability of the technical means to bring about 'the ancient dream of mankind - a world without poverty.' When such means make fulfilment of the 'ancient dream' possible, says Kissinger, 'our profound moral convictions make it also our duty.' Like Truman before him, the content of the duty was not to transfer material resources, but to share American knowledge. ${ }^{65}$ Recall that for Truman in 1947, '[t]he United States is pre-eminent among nations in the development of industrial and scientific techniques. The material resources which we can afford to use for assistance of other peoples are limited. But our imponderable resources in technical knowledge are constantly growing and are inexhaustible' ${ }^{66}$ For Truman then and Kissinger after him, the existence of human suffering, and superior technical knowhow, authorises, as Grovogui puts it '...a Western [and here, specifically American] claim to moral authority as a provider of rules and models to the rest. ${ }^{67}$

\footnotetext{
${ }^{61}$ Azeredo Da Silverira (Brazil), 'Address delivered at $2327^{\text {th }}$ Plenary Meeting', Official Records of the United Nations General Assembly (1 September 1975, New York), [3], citing United Nations General Assembly, 'Resolution adopted by the General Assembly: 3172 (XXVIII) Holding of a special session of the General Assembly devoted to development and international economic co-operation', GA Res 3172 (XXVIII), 17 December 1963, UN Doc A/RES/28/3172.

62 Daniel Moynihan (United States of America), 'Address delivered at 2327th Plenary Meeting', Official Records of the United Nations General Assembly (1 September 1975, New York), [33]-[203].

63 Bernard Gwertzman, 'Kissinger Seeks Approval Today of Mideast Pact', The New York Times (1 September 1975). Available at: https://www.nytimes.com/1975/09/01/archives/kissinger-seeks-approval-today-of-mideast-pact-works-withisraelis.html [website last visited 5 June 2018].

64 Moynihan (1975), above n 61, [35-36]. Kissinger served as US Secretary of State from 1973 - 1977.

65 Harry Tuman, 'Truman's Inaugural Address', Harry S. Truman Presidential Library and Museum (20 January 1949). Available at: https://www.trumanlibrary.org/whistlestop/50yr_archive/inagural20jan1949.htm [website last visited 11 June 2018].

66 Truman (1949), Ibid,

67 Siba Grovogui, 'Come to Africa: A Hermeneutics of Race in International Theory', Alternatives: Global, Local, Political, 26/4 (2001) 425-448, 427.
} 
The claim to moral authority grounded in scientific knowledge is the flip side of the way Pogge's account in 2002, of the moral responsibility of the 'developed West', ${ }^{68}$ has the effect of authorising its actions vis à vis 'the poor'. The 'poor' for Pogge, 'can cause little harm or benefit to the politicians and officials who rule them', ${ }^{69}$ because of the afflictions of poverty: they are 'often physically and mentally stunted due to malnutrition in infancy, illiterate due to lack of school, and much pre-occupied with their family's survival. ${ }^{70}$ Their abjection and political disenfranchisement means 'the poor' must be both helped, and spoken for now by 'those who live in protected affluence', in the 'developed West'. ${ }^{71}$ Newly enlighted, today's generations of 'European civilization', ${ }^{72}$ now 'widely accept' 'the equal moral status of all human beings', and must therefore take up the salvific responsibility that 'equal moral status' confers upon the fortunate, not to 'tolerate' extreme poverty. This moral obligation, in Pogge's view, should operate as a constraint on 'the kinds of global economic order persons may impose on others. ${ }^{73}$ In this acknowledged capacity to 'impose' a global economic order on others, a power differential is acknowledged, but agency to act - and to authorise law - still inures only in the fortunate, not in 'the poor'.

The role of history in producing the capacity to 'impose' economic order is also attenuated in both Pogge and Kissinger's accounts. In contrast to the Third World's insistence on the continued presence of history, and the active impoverishment by the West of the rest, for Kissinger the moment from which he spoke was ruptural, representing a radical break with the past: the 'global order of colonial power that lasted through centuries has now disappeared' ${ }^{74}$ In contrast to Kissinger, Pogge in a later article, does 'recall briefly that existing peoples have arrived at their present levels of social, economic and cultural development through an historical process that was pervaded by enslavement, colonialism, even genocide', ${ }^{75}$ but like Kissinger, Pogge announces a definitive break, as 'these monumental crimes are now in the past. ${ }^{176}$ For him, the importance of the 'legacy' they have left does not reside in the dominance of the particular forms of (international) law or knowledge that those practices were crucial in actualising, but 'a legacy of great inequalities'. Pogge draws a line in the midtwentieth century, under the moment when 'Europe released Africa from the colonial yoke'.77 This line then becomes the point of departure for the universalist argument that 'we' have a moral

\footnotetext{
68 Pogge (2002), above $n 4$.

69 Pogge (2002), Ibid, 29.

70 Pogge (2002), Ibid.

71 Pogge (2002), Ibid, 30.

72 Pogge (2002), Ibid.

73 Pogge (2002), Ibid, 32.

74 Moynihan (1975), above $n$ 61, [38].

75 Pogge (2005), above n 8, 723.

76 Pogge (2005), Ibid.

77 Pogge (2005), Ibid.
} 
responsibility to 'the global poor', because of the 'initial economic inequality'78 which tends to benefit 'the stronger party'.

For Kissinger, the present was so new, that by 1972, even 'the cold war division of the world into two rigid blocs ha[d] now also broken down', and there remained, he said, only states united in the common endeavour of development. ${ }^{79}$ But because of its obvious under-development, action taken by the Third World at the international institutional level could not be read as the assertion of a different account of (international) law. Instead, Third World solidarity was positioned in opposition to the inauguration of what could be a new era of 'human progress'. The threat lay in the formation of the Non-Aligned Movement, a 'new bloc' which was counter-productive to this endeavour, engaging 'in a kind of solidarity that often clearly sacrifices practical interests' ${ }^{80}$ What was required to address the economic problems faced by all states was not division, said Kissinger, but 'consensus, first and foremost, on the principle that our common development goals can be achieved only by cooperation, not by the politics of confrontation' ${ }^{81}$

The 'transnational enterprise' was amongst the most contentious of these lines of 'political division'. The ongoing 'controversy over their role and conduct' which had continued in various forms and fora since Allende's speech was 'itself an obstacle to economic development' ${ }^{82}$ In his view, 'if the world community [was] committed to economic development, it [could] not afford to treat transnational enterprises as objects of economic warfare. ${ }^{83}$ Nevertheless, Kissinger conceded that 'the time [had] come for the international community to articulate standards of conduct' for corporations, and acknowledged that the UNCTC, 'had begun such an effort'. But for Kissinger, 'transnational enterprises ha[d] been powerful instruments of modernization', and 'may well be one of the most effective engines of development'. ${ }^{84}$ As Allende had foreshowed, 'foreign investment' was imputed with a tutelary dimension, and tied closely to an exogenous, salvific project of developing the underdeveloped. For Kissinger, given that only 'transnational enterprises' and the private capital they provided could facilitate the solution to the problem of under-development, standards should be formulated which applied both to the behaviour of corporations and to the governments that hosted them. ${ }^{85}$

\footnotetext{
78 Pogge (2005), lbid. My emphasis.

79 Moynihan (1975), above $n$ 61, [38].

80 Moynihan (1975), Ibid, [44].

81 Moynihan (1975), Ibid, [47].

82 Moynihan (1975), Ibid, [105].

83 Moynihan (1975), Ibid, [119].

${ }^{84}$ Moynihan (1975), Ibid, [103].

85 Moynihan (1975), Ibid, [108].
} 
The principles that Kissinger laid out underpinning these standards were extensive, but two elements were key to the question of the transnational corporation. First was an insistence that corporate conduct should be governed by local, not international law. Transnational corporations were of course 'obliged to obey local law' and should 'refrain from unlawful interference in the domestic affairs of the host country', and 'respect local customs and employ qualified local personnel'. ${ }^{86}$ But second, in return, those corporations must receive a stable, apolitical environment in which to operate, characterised by equitable and non-discriminatory treatment. And unlike corporate conduct governed by local law, 'host states' must accord transnational enterprises protection 'in accordance with international $l a w^{\prime} .^{87}$ In Kissinger's account, these protections would be supported by a suite of international endeavours, including the harmonisation of tax treatment, the promotion of arbitral procedures for the settlement of investment disputes, the reduction of restrictive business practices, and the multilateralization of the insurance of foreign investment. ${ }^{88}$ These would be underpinned by the 'development of agricultural technologies' for food production, 'assistance to improve productivity and competitiveness' in relation to non-agricultural food production, and the assurance of future access to 'borrowing in the [international] capital market', which was already relied upon heavily in the Latin American countries. ${ }^{89}$ In essence, what Kissinger was mapping was a different kind of 'new international economic order', one which drew for its authority on 'development', and the needs of the poorest 'one billion people', ${ }^{90}$ but which precisely contradicted in its every element the other 'New International Economic Order' being proposed by the Global South at the same moment.

As we know now, Kissinger's map was prefigurative of what was to come. What looked like a victory of sorts in the creation of the UNCTC, failed to produce the collective state action sought by the Third World to regulate the conduct of multinational corporations. The UNCTC was quietly put to rest in 1993, folded into the UNDP as part of the 'Division on Investment and Enterprise.' But more than portending a simple failure, Kissinger's detailed plan forshadowed the eventual inversion of what was being attempted by the Third World, and the preclusion of the exercise by the Third World, of juridical authority. Today that particular attempt to establish a conversation at the United Nations about multinational corporations is almost invariably forgotten. ${ }^{91}$ When it is remembered at all, it is usually characterised as an ill-fated attempt to assert a Third World sovereign jurisdiction against an

\footnotetext{
86 Moynihan (1975), Ibid, [110].

87 Moynihan (1975), Ibid, [111]. Emphasis added.

88 Moynihan (1975), Ibid, [112]-[118].

89 Moynihan (1975), Ibid, [84].

90 Moynihan (1975), Ibid, [165].

${ }^{91}$ For one notable exception to this, see Jennifer Bair, 'Corporations at the United Nations: Echoes of the New International Economic Order', University of Pennsylvania Press, 6/1 (2015) 159-171.
} 
international jurisdiction, with all the hierarchies of value that characterisation implies. The story is now largely retold (for better or worse) as 'sovereignty' versus international 'community'.

But slowing the story down reveals that what was being asserted was not the simple 'domestic' versus 'international' story, but the authority to decide which matters should be put into the basket of 'domestic', which should be 'ínternational', and with what consequences. As it emerged from formal empire, the Third World sought to assert authority over private property in the national realm as a way to address the economic legacies of imperialism, and to internationalise the capacity to regulate corporate conduct as a response to the essential rootlessness of the multinational corporation.

This manifests precisely with respect to 'global' corporations and their operations at large. What we have seen during the period from the end of the Cold War to the present is the internationalization of the protection of private property through an emerging regime of 'international investment law', ${ }^{92}$ and the relegation to the national sphere of the regulation over corporate conduct, along with the vulnerabilities and collective action problems that brings. This has been accompanied by a turn to 'business and human rights' which pushes responsibility for enforcing the standards downwards into the (Third World) nation-state, but invests authority over setting the standards themselves upwards, into the international community through its jurisdiction over the universal 'human'. ${ }^{93}$

\title{
III. Conclusion
}

To those who believe that Europe and North America have already invented a universal civilization and all the rest of us have to do is hurry up and enrol, what I am proposing will appear un-necessary if not downright foolish. But for others, who may believe with me that a universal civilisation is nowhere yet in sight, the task will be how to enter the preliminary conversations.

\author{
Chinua Achebe, Today, The Balance of Stories ${ }^{94}$
}

\footnotetext{
92 Sundhya Pahuja, 'Part 3: Contemporary Patterns of Ordering: Business and Human Rights and International Investment Law', Hersch Lauterpacht Memorial Lectures (March 2018, University of Cambridge). Available at: https://www.lcil.cam.ac.uk/hersch-lauterpacht-memorial-lectures [website last visited 15 June 2018]. See Muthucumaraswamy Sornarajah, 'The Myth of International Contract Law', Journal of World Trade Law, 15 /3 (1981) 187217. On the 'levitation' out of the sphere of domestic law into that of international law, see Muthucumaraswamy Sornarajah, Law of International Joint Ventures (Spore: Longman, 1992), 298.

93 United Nations Human Rights Office of the High Commissioner, 'Guiding Principles on Business and Human Rights: Implementing the United Nations "Protect, Respect and Remedy" Framework' (Geneva: United Nations, 2011); Erika George, 'Incorporating Rights: Empire, Global Enterprise and Global Justice', University of St. Thomas Law Journal, 10 (2013) 917.

${ }^{94}$ Chinua Achebe, 'Today, the Balance of Stories', in Chinua Achebe, Home and Exile (New York: Oxford University Press, 2000), 104.
} 
This chapter is not an (intellectual) history in the sense of tracing an idea of 'Global Justice' as it emerges, travels from one place to another, and touches down in academic or institutional contexts. Instead, it is an approach which considers particular articulations of the kinds of arguments about justice and distribution, and inequality and material deprivation, made at the level of international law and institutions over time, and the practices such arguments authorise. Thinking of law as practice and technique, rather than concept and norm, helps us to see the ways such authorisation happens through specific actors, and groups of actors authoring particular accounts of the world which include a story about how particular kinds of relationships should be understood, what counts as problems, and what should be done about them. In this it shares the intuition that normative and descriptive accounts of the world - the 'is' and the 'ought' - are thought, performed and actualised together, or in Jasanoff's idiom, 'co-produced'. ${ }^{95}$

In the example given here, contestations over how to hold the corporation to account at the end of European imperialism, reveal three things. The first is that at least two rivalrous accounts were explicitly doing battle at the institutional level during the 1970's and 80's. The second is that each account carried with it, an explanation for the causes of material deprivation, which invited different normative approaches to what should be done about it. The third is that these accounts can be understood as 'rival' accounts in the formal sense that each generated - and was generated from within - a different understanding of the whole world. They are not two poles on one scale, between which a 'balance' can be struck. Instead, they exist in a relation of what we might call 'radical plurality' insofar as no single set of institutions can accommodate - or actualise - both world views. ${ }^{96}$

The central point of differentiation between the two approaches is the question of authority. It plays out explicitly with respect to the global corporation, in the way that the Third World sought national control over the property question, and international agreement over the conduct question, and the inversion of that demand by a suite of US-led initiatives. But the prior question is the question of who has the authority to decide. This extends to the question of who may decide what counts as law. It is fairly clear that since the end of formal empire, Third World states have consistently sought a capacity

\footnotetext{
95 Jasanoff (2004), above $n$ 5, 1-12, especially 1-6.

96 Paul Voice, 'Global Justice and the Challenge of Radical Pluralism', Theoria: A Journal of Social and Political Theory, 104 (2004) 15-37. I am borrowing Voice's definition of what he calls 'radical pluralism', but adapting it to an account of plurality. An 'ism' suggests an orientation toward a thing, wheras an '...ity' denotes a state, not an attitude. People often use the word 'legal pluralism' (for example) to describe both a theoretical orientation toward being attentive toward multiple laws and the fact of that plurality itself. This is to confuse two elements, the fact of legal plurality, which exists regardless of one's attitude (for example, indigenous law and colonial law), and what kind of response scholars and institutions may have to that fact.
} 
to determine their own affairs. ('The notion of justice is not complicated. It is universally accepted that a dominance of one people by another, or one group by another, must be ended so that equality is restored.' $)^{97}$ They have put forward a corollary account of international law and institutions as an agonistic space of meeting. ${ }^{98}$

It is similarly clear that Western states have asserted the authority to decide not only for themselves, but for everyone ('humanity'), and everything ('global economy'), on the basis of a claim to the universality of their asserted law. ${ }^{99}$ ('International law does not recognize any distinctions...based on religious, geographical or cultural differences.') ${ }^{100}$ The 'First World' put forward a corollary account of international law and institutions as directed toward 'governing'. Because of its asserted universality, this law positions itself above, rather than between, plural entities. Once a law is asserted as inclusive regardless of difference, the inclusive, universally oriented law authors the jurisdictional forms which give shape to life, and authorises the governance of the other. And so although this claim to universality is asserted as a virtue which carries the promise of inclusion and universal access to moral rights, when combined with power, it has the effect of dominating those who are included within it.

The mechanisms, stories, practices and arrangements which permit this assertion, and its actualisation are many. Developmentalism, or the scalar organisation of states according to putatively economic criteria, has done much of the work in recent years to sustain the claim to universality made by the West. Notwithstanding the fact that many understand this, 'the languages of post-Enlightenment constitutional arrangements' ${ }^{101}$ are still assumed to be sufficient in international institutions, and in almost all official centres of international law making and foreign policy. This is perhaps unsurprising given that the 'axiomatics of imperialism' have always been intended to 'reproduce the systems, values, norms and institutions [...] that preserve vested interests under the guise of truth. ${ }^{102}$

\footnotetext{
97 Muthucumaraswamy Sornarajah, 'On fighting for global justice: the role of a Third World international lawyer', Third World Quarterley, 37/11 (2016) 1972-1989, 1972.

98 On an agonistic conception of democratic politics, see Chantal Mouffe, 'Agonistic Democracy and Radical Politics', Pavilion Journal for Politics and Culture (n.d.). Available at: http://pavilionmagazine.org/chantal-mouffe-agonisticdemocracy-and-radical-politics/ [website last visited 15 June 2018]; William Connolly, Pluralism (Durham, Duke University Press, 2005). On laws of encounter, see Pahuja (2017), above n 24 and Sundhya Pahuja, 'Laws of encounter: a jurisdictional account of international law', London Review of International Law, 1/1 (2013) 63-98.

${ }_{99}$ The claim to universality arguably extends to existence as a whole, not just law. There are many books devoted to this idea. For one recent example, see Hamid Dabashi, Can Non-Europeans Think? (London: Zed Books, 2015).

100 Jennings and Watts (1997), above $n 1$.

101 Grovogui (2012), above n 9, 107

102 Grovogui (2012), above n 9 lbid. Grovogui is taking 'axiomatics of imperialism' from Gayatri Spivak, A Critique of Postcolonial Reason: Toward a History of the Vanishing Present (Cambridge: Harvard University Press, 1999).
} 
Perhaps more surprising is the way that those engaged critically with the developmental scale, and those who have tried to re-define development in a legal and institutional context, have forgotten that the origins of the scale lie in a racialized understanding of theories of history, justice and science. ${ }^{103}$ The forgetting of race means the concealment of its persistence as an organising idea. And so by the end of the Cold War, at the level of international law and institutions, race had been contained by the 'territorial trap' of the nation-state, ${ }^{104}$ and transformed into a domestic issue, both institutionally and phenomenologically. ${ }^{105}$ With this, the roots of contemporary economic structures in 'scientific' theories of biological racial inferiority are both erased and the political and moral theories which flow from them are 'exonerated' of their racism. ${ }^{106}$

\footnotetext{
103 Grovogui (2012), Ibid.

104 Agnew (1994), above $n$ 9, 53-80.

105 Gordon et al. (2015), above $n 5,2$.

106 Grovogui (2012), above n 9. See generally, Joel Modiri, 'The colour of law, power and knowledge: introducing critical race theory in (post-)apartheid South Africa', South African Journal on Human Rights, 28 (2012) 405-436. For a recent example of the way a cultural account of difference exonerates the racialized underpinnings of that account, see Martti Koskenniemi, 'Race, Hierarchy and International Law: Lorimer's Legal Science', European Journal of International Law, 27/2 (2016) 415-429. By distinguishing Lorimer's explicitly race based account from other international lawyers of the time, Koskeniemmi is missing the racialized underpinnings of those putatively 'cultural' accounts.
} 


\section{University Library}

\section{- M M N E R VA A gateway to Melbourne's research publications}

Minerva Access is the Institutional Repository of The University of Melbourne

Author/s:

Pahuja, S

Title:

Corporations, Universalism, and the Domestication of Race in International Law

Date:

2019

Citation:

Pahuja, S. (2019). Corporations, Universalism, and the Domestication of Race in

International Law. Bell, D (Ed.). Empire, Race and Global Justice, (1), pp.74-93. Cambridge University Press.

Persistent Link:

http://hdl.handle.net/11343/251325 